Iwona Lindyberg

Uniwersytet Gdański

\title{
Warsztat Terapii Zajęciowej w doświadczeniach dorosłych osób z głębszą niepełnosprawnością intelektualną
}

Artykuł porusza tematykę wsparcia w dorosłości osób z głębszą niepełnosprawnością intelektualną w ich własnej perspektywie. W artykule zostały "odsłonięte” i zinterpretowane znaczenia nadawane, przez osoby badane, Warsztatowi Terapii Zajęciowej jako istotnemu miejscu ich wsparcia.

Słowa kluczowe: niepełnosprawność intelektualna, dorosłość, wsparcie

\section{Occupational Therapy Workshop in the experiences of adults with moderate and severe intellectual disability}

The article is devoted to the support for adults with moderate and severe intellectual disabilities in their own perspective. The presented text aims to illustrate the revealed and interpreted meanings participants ascribe to the occupational therapy workshop as the very important place to receive support.

Keywords: intellectual disability, adulthood, support

\section{Wprowadzenie}

Warsztaty Terapii Zajęciowej (WTZ) funkcjonują, w polskim systemie wsparcia dorosłych osób z niepełnosprawnością, od 1991 roku. Przez lata istnienia nie zmieniały się główne ustawowe cele funkcjonowania tych placówek, to niewątpliwie praktyka rehabilitacyjna "odsłaniała” wiele niespójności w ustawowych zapisach czy też rozbieżności co do możliwości wypełniania misji warsztatu. Rozbieżność dotyczy w dużej mierze zakładanych celów do realizacji przez warsztaty i możliwości ich realizacji w stosunku do bardzo zróżnicowanej grupy osób z niepełnosprawnością. 
Według najnowszego Raportu PFRON Warsztaty Terapii Zajęciowej „pełnią bardzo ważną rolę $\mathrm{w}$ życiu dorosłych osób niepełnosprawnych, które nie są w stanie podjąć zatrudnienia, a w swym codziennym funkcjonowaniu wymagają opieki i wsparcia ze strony innych osób, bowiem zapewniają swym uczestnikom rehabilitację społeczną i zawodową, a także przyczyniają się do podniesienia jakości ich życia i aktywnego włączania się w życie społeczne" [Raport PFRON, 2014, s. 16].

Dzięki korzystaniu z działań terapeutycznych w takich instytucjach, jakimi są Warsztaty Terapii Zajęciowej, osoby z niepełnosprawnością mogą:

- „uczestniczyć w życiu grupy, nawiązywać relacje i przeżywać związane z nimi emocje, nabywać umiejętności społeczne i poznawać formy współżycia w grupie;

- rozwijać sprawności psychofizyczne niezbędne w pracy oraz podstawowe i specjalistyczne umiejętności zawodowe umożliwiające zatrudnienie w zakładzie aktywności zawodowej lub otrzymanie innej pracy zarobkowej;

- podejmować celową aktywność, najczęściej związaną z ekspresją twórczą oraz prostymi czynnościami wytwórczymi leżącymi w zakresie możliwości uczestników warsztatu;

- zdobywać kompetencje i wykonywać czynności związane z prowadzeniem gospodarstwa domowego - dotyczy to szczególnie działalności kulinarnej;

- uczestniczyć w różnych formach aktywności kulturalnej;

- poprawiać swoją sprawność oraz kondycję fizyczną i psychiczną, a tym samym niezależność i samodzielność funkcjonowania;

- uczestniczyć w życiu społeczności lokalnej" [Anasz, Mrugalska, Wojtyńska, Ferenc 2014, s. 72].

Praktyka rehabilitacyjna pokazuje, że osoby z niepełnosprawnością intelektualną są specyficznym klientem usług dedykowanych im $w$ instytucjach wsparcia w dorosłości. Według Raportu PFRON z 2014 roku: „najliczniej reprezentowaną grupą osób niepełnosprawnych w rozumieniu głównej dysfunkcji (czyli takiej, która ma decydujący wpływ na możliwości psychofizyczne uczestnika warsztatu) są osoby z niepełnosprawnością intelektualną (57\%), przede wszystkim w stopniu znacznym (33,4\%)" [Raport, 2014. s. 64]. Jak podkreślają autorzy Raportu: „gdy pod uwagę weźmiemy nie tylko główną dysfunkcję, ale również niepełnosprawności sprzężone, udział tej grupy wśród ogółu uczestników wzrasta do 64\%. Warto zauważyć, iż w ponad połowie WTZ (55\%) osoby z upośledzeniem umysłowym są najliczniejszą grupą (stanowią ponad połowę uczestników), zaś w co czwartym WTZ całkowicie dominują (stanowią powyżej trzech czwartych wszystkich uczestników)" [tamże, s. 64-65].

Korzystanie ze wsparcia w WTZ przez osoby z głębszą niepełnosprawnością intelektualną budzi wiele wątpliwości, które głównie dotyczą realizacji celu ustawowego jakim jest aktywizacja zawodowa. E. Zakrzewska-Manterys opisała 
w tym kontekście specyfikę funkcjonowania osób z niepełnosprawnością intelektualną, ujmując to w następujący sposób: „są osobami na tyle specyficznymi, że nie można w stosunku do nich mechanicznie stosować ani zapisów konwencji, ani też innych dokumentów prawnych dotyczących szeroko rozumianej kategorii niepełnosprawności. Uważam, że osoby te stanowią podkategorię niepełnosprawnych wyłącznie z powodów prawno-administracyjnych: są mniejszością, której specyfikę należy chronić. Natomiast z powodów praktycznych, życiowych osoby te różnią się od wszystkich innych osób niepełnosprawnych w zasadniczy, fundamentalny sposób: wszyscy niepełnosprawni oprócz nich wymagają wsparcia, aby móc samodzielnie funkcjonować. Oni jedyni nigdy nie będą mogli samodzielnie funkcjonować - wsparcie nie jest dla nich warunkiem startu w samodzielność, jest natomiast niezbywalną okolicznością towarzyszącą ich całemu życiu [Raport PFRON, 2014, s. 28].

\section{Ramy metodologiczne}

Zdaniem D. Lalak [2014, s. 16] „Badania biograficzne charakteryzuje niepowtarzalność, epizodyczność, wydarzeniowość oraz powinowactwo badacza i badanego. Jedną ze specyficznych cech badań biograficznych jest prymat przedmiotu badań nad metodą. Z jednej strony to, jak zauważa autorka, niewątpliwa zaleta, bowiem tego typu badania są zogniskowane na badaniu konkretnych zjawisk codziennego doświadczenia w kontekście całego ludzkiego życia, ale też i słabość, ponieważ sposób postrzegania biografii odwołuje się do wielu ujęć paradygmatycznych, niemożliwe więc staje się zdefiniowanie ich wspólnego mianownika, tak w wymiarze teoretycznym, jak i metodycznym" [Lalak 2014, s. 16].

M. Chodkowska [2014, s. 138] twierdzi, iż metoda biograficzna może być w pedagogice specjalnej „zarówno procedurą badawczą znajdującą uprawomocnienie w różnych teoriach, do których ta dyscyplina nawiązuje, w potrzebach poznawczych samej pedagogiki specjalnej, w różnych wątkach jej teorii, jak i metodą praktyczną, wypełniającą szereg funkcji zarówno wobec osób z niepełnosprawnością, jak i wobec pełnosprawnych, zwłaszcza funkcji na rzecz rzeczywistej społecznej integracji obydwu tych grup w różnych obszarach ich wspólnych przestrzeni i w różnych etapach życia". Warto jednak zauważyć, że pomimo możliwości i szans jaką dają badania biograficzne, jeszcze do niedawna nie były one częstą praktyką w badaniu doświadczeń osób z niepełnosprawnością intelektualną. Te bogate możliwości metody biograficznej są w pedagogice specjalnej nadal wykorzystywane w niewielkim stopniu. Zdaniem M. Chodkowskiej problemy w realizowaniu tego typu badań w pedagogice specjalnej mogą wynikać ze specyficznej procedu- 
ry badawczej, na którą składa się zarówno „gromadzenie, jak i opracowywanie tego rodzaju materiałów oraz takie ich przechowywanie, by mogły być wykorzystywane dla celów analizy porównawczej w różnych procedurach badawczych" [Chodakowska 2014, s. 138].

Zdaniem M. Pryszmant-Ciesielskiej [2014, s. 32] w badaniach biograficznych „elementy (samo)wiedzy, czy też wymiary usytuowania, tworzą pewnego rodzaju „kalejdoskop”, przez który badacz poznaje świat społeczny, przy czym za każdym razem jest to jakiś niepowtarzalny układ elementów, konstelacja, która warunkuje różną perspektywę poznania mikroświatów społecznych" [2014, s. 32].

Według J. Łukasik „doświadczanie zdarzeń w każdej sytuacji życia codziennego to nic innego, jak rozumienie ich w sposób osobisty i bezpośredni (...) to indywidualne ukazanie własnego dążenia, to świadectwo własnego życia" (Łukasik 2013, s. 11].Istotny jest fakt, iż zdaniem autorki „refleksja nad codziennością, codzienną rzeczywistością pozwala dookreślić i nadać inny sens temu doświadczeniu" [2013, s. 110].

Przeszłe doświadczenia istnieją na poziomie pamięci biograficznej, a przeszłość jawi się tu jako swoistego rodzaju „magazyn doświadczeń", czyli jako obszar, który stanowi o naszej niepowtarzalności i tożsamości Warto podkreślić, iż zwracanie się ku przeszłości jest niezbędne człowiekowi z wielu powodów. Główny powód jednak jest taki, że czerpiemy z przeszłości informacje o sobie, oraz sięgamy do przeszłości także po to, by wykorzystać to czego się już nauczyliśmy, a co jest pomocne w codziennym życiu [Bugajska,Timoszyk-Tomczak 2010, s. 110].

Niewątpliwie trudno w pełni odnieść te słowa do doświadczeń osób z głębszą niepełnosprawnością intelektualną, a raczej do tego co "dzieje się" w tych osobach, w jaki sposób ich doświadczenia zmieniają ich samych i w jaki sposób oni sami kreują następne doświadczenia.

Badania jakie podjęłam dotyczą znaczeń nadawanych przez dorosłe osoby z umiarkowanym stopniem niepełnosprawności intelektualnej miejscu, które w związku z biograficznym uwikłaniem stało się dla nich bardzo ważne jako środowisko wsparcia. Miejscem, o którym mowa, jest Warsztat Terapii Zajęciowej. Każda z badanych przeze mnie osób trafiła do warsztatu zaraz po zakończeniu edukacji. Nie mają więc żadnych innych doświadczeń dotyczących innych miejsc wsparcia poedukacyjnego. Osobami badanymi są 4 osoby z umiarkowanym stopniem niepełnosprawności intelektualnej: Krzysztof (27 lat), Łukasz (26 lat), Monika (28 lat) i Anna (28 lat). Wszyscy są absolwentami Specjalnego Ośrodka Szkolno-Wychowawczego. Badani to osoby dość samodzielne społecznie i komunikatywne. Badania przeprowadziłam $\mathrm{z}$ wykorzystaniem indywidualnych wywiadów pogłębionych i wywiadów grupowych. 


\section{Analiza i interpretacja zebranego materiału}

W zebranym materiale wyłoniłam pewne kategorie, wokół których zogniskowane były główne znaczenia nadawane przez badanych Warsztatowi Terapii Zajęciowej, a więc placówce, z wsparcia której badani od kilku lat korzystają.

\section{Element codziennego życia}

Dla badanych przeze mnie osób WTZ stał się stałym elementem ich codziennego życia. Każda z badanych osób zaaklimatyzowała się dość szybko w warsztacie i to właśnie ta placówka jest dla nich istotnym środowiskiem poza domem rodzinnym.

Oto fragment wywiadu grupowego, w którym „odsłaniają się" znaczenia jakie badane osoby nadają warsztatowi w kontekście własnej codzienności:

K: przychodzę z Warsztatu tu w sobotę sprzątam swój pokój. A wczoraj jak wrócitem to zjadłem obiad, musiałem dać kotom jeść. Dokarmiam koty... Daję wodę, mleko. Ogladam w domu telewizję... serial: Na dobre i na złe oglądam. Spać chodzęo 9 albo o 10, a potem znów idę do Warsztatu.

Ja: A kolację to robisz sobie sam czy mama Ci robi?

K: Mama mi robi śniadanie, I mama mnie budzi... za 10 siódma mnie budzi. Zjem śniadanie, ogolę się, umyję zęby i się ubieram na warsztaty.

A: Ja idę szybko spać, bo wyspać się muszę, aby na warsztaty iść i wszystko zatatwić.

Ja: A co takiego załatwiasz?

A: A dużo. Sprzątam po śniadaniu i dyżur mam w kuchni i kleję takie pudełka i kwiaty podlewam.

K: Ja też sprzątam i śmieci wynoszę i rysuję i w przedstawieniu występuję.

M: Też sprzątam w Warsztacie.

J: A w domu sprzątasz?

E: Nie tak często. Mama się denerwuje... nie lubię tego wycierania i szczotki... sprzątania nie lubię.

$K:$ Na warsztatach sprzątasz?

Ł: Muszę. A potem w domu odpoczywam.

Badani z pewną trudnością wymieniają czynności, które są ich udziałem $\mathrm{w}$ warsztacie. Niewątpliwie zwraca uwagę użyte przez jednego $\mathrm{z}$ badanych określenie: „załatwić". Nie wydaje się ono tu adekwatne, bowiem pobyt w WTZ nie ma charakteru okazjonalnego, podczas którego można by coś załatwić. Według mnie podkreśla jednak ważność tych działań i wiem, że badany użył go celowo. Wszyscy rozmówcy nie pytani o to wymieniali różne czynności, które wykonują 
$\mathrm{w}$ warsztacie. $\mathrm{W}$ indywidualnych narracjach zebranych podczas wywiadów indywidualnych sami poruszali wątek codziennej bytności w placówce.

K: Teraz sam chodzę do Warsztatu. Nie z mama. W domu mama czeka i moje zwierzęta czekają... aż wrócę. I jestem zmęczony, to jak zjem obiad i odpoczywam... to wtedy muszę sprzątnać klatki (...), a kolację zjem i pójdę spać i idę do Warsztatu.. .i do weekendu tak chodzę... potem odpoczynek jest $i$ śpię, telewizję oglądam, mamie pomagam.

A: Tak już przyzwyczajona jestem, że wstać trzeba rano i spakować się (...), a ciuchy to wieczorem mam naszykowane na krześle. Sama wybieram. Mam nie wtrąa się. Tyle się przygotuję i potem mogę wyspać się i śniadanie zjem. Sama robię czasem i mamie też, jak jej się nie chce wstać, bo na zwolnieniu byta. A jak idzie do pracy, to mama robi i wychodzę na tramwaj, a potem idę na warsztaty. I tu tez robię i sprzatam.

Ł: W Warsztacie dużo roboty, a ja nie lubię pracować za bardzo (...), w domu nic nie chce mi się robić, bo zmęczony jestem i mówię mamie, że odpocznę (...) i kłócę się, bo mama mówi, że do zlewu kubek mam zanieść.. to ja na warsztatach robię... po śniadaniu... do zlewu... w domu zostawiam (...) często zostawiam i mama się denerwuje.

M: Lubię tu przychodzić. Jak zdrowa jestem, bo jak chora to w domu jestem na zwolnieniu i leżę, odpoczywam. Sama leżę, bo mama w pracy jest (...) wolę tu przyjść i rano ćwiczenia mam... rowerek i ćwiczę... a potem w kuchni i rysowanie jakieś (...) sprzatam też po zajęciach i idę do domu.

Powyższe wypowiedzi nie były jakoś szczególnie przeze mnie prowokowane. Badani sami niejednokrotnie wracali do codziennej rutyny i usiłowali umiejscowić pobyt $w$ warsztacie w strukturze własnej codzienności. Uważam, że powtarzalność pewnych działań i ich przewidywalność dawać może im poczucie bezpieczeństwa. Są przekonani o nabywaniu w warsztacie pewnych kompetencji. Mają pewną świadomość tego, że uczą się nowych czynności i podejmują się nowych dla siebie aktywności. Zdaniem D. Wolskiej: „osoby z głębszą niepełnosprawnością intelektualną, aby odnaleźć swoje miejsce w społeczeństwie, rodzinie, w pracy, powinny w biegu całego życia opanować umiejętności, które pozwolą im sprostać zadaniom i wymaganiom, jakie stawia codzienne życie" [Wolska 2016, s. 21]. To codzienne życie dla badanych to nie tylko ich dom, ale i miejsce, do którego uczęszczają zaznajomieni już dobrze z pewnym rytmem dnia w warsztacie, wymaganiami i obowiązkami.

\section{Świadectwo dorosłości}

Istotnym punktem odniesienia dla poszczególnych narracji badanych osób dotyczących warsztatu stały się ich wcześniejsze doświadczenia edukacyjne. Wielokrotnie podczas wywiadów badani wracali do doświadczeń związanych ze szkołą. Wszystkie badane przeze mnie osoby to absolwenci jednego Specjalnego 
Ośrodka Szkolno-Wychowawczego. Wszyscy kończyli też naukę w podobnym okresie i widywali się w szkole.

Temat wcześniejszej edukacji nie był przeze mnie wywołany. Ten wątek pojawił się sam i okazał się bardzo istotny dla moich rozmówców. Badani wielokrotnie wracali do szkolnych doświadczeń w kontekście obecnego wsparcia, z którego korzystają $w$ WTZ. Jedno $z$ istotnych uzgodnień, jakie poczynili podczas wywiadu grupowego, to było uzgodnienie, które nazywam „zerwaniem z dzieciństwem". Tak naprawdę chodzi o symboliczne pożegnanie się z byciem dzieckiem. Możliwość przejścia do warsztatu stała się dla wszystkich moich rozmówców zmianą, którą w naturalny sposób zaakceptowali i której nadają znaczenie „przejścia" w dorosłość.

Oto wybrane fragmenty wywiadu grupowego, podczas którego ten wątek się pojawil:

K: To była szkoła... To był ośrodek szkolny... tam... specjalny. I płakałem, bo już nie mogłem tam chodzić, ale w warsztacie to mi się od razu spodobało (...) i pan kierownik $i$ wszystkie panie mite... już cieszyłem się i nie ptakatem (...), mama ptakata jak sobie poradzę, a ja nie ptakałem... ani trochę.

Ł: Też lubiłem do szkoty chodzić. Lubię, I tam miałem panią Izę, panią Małgosię. A jak po szkole do warsztatu przyszedtem, to mi się spodobało. Musiałem zobaczyć czy mi się spodoba warsztat. I byłem pierwszy raz w listopadzie zobaczyć jak mi się spodoba i jak mi będzie szło. I jestem $w$ warsztacie teraz. Fajnie jest. W szkole też fajnie.

K: To już dzieci tam chodza, a ja nie jestem dzieckiem.

Ł: Ja też. Dorosty jestem.

A: Lubię tu chodzić, bo mama nie chciała abym szła do pracy po szkole. Co ja bym robiła? W domu siedziata? A tak to i zajęcie mam.

Ł: Ja też zajęcie mam.

M: Ja przyszłam na warsztaty... tu. Bo szkoła już skończyła się, a ja mam teraz warsztaty. Do szkoty już nie było jak.

W powyższej narracji uwidacznia się kontekst rodzinny. Badani dość często $\mathrm{w}$ różnych fragmentach indywidualnych narracji, czy tych pozyskanych podczas wywiadów grupowych, wspominali o swoich rodzicach. Najbliższe im osoby są dla nich znaczącymi i to właśnie na ich postawy, reakcje czy też emocje oni sami zwracają swoją uwagę. Dla moich rozmówców istotne stały się przede wszystkim postawy rodziców wobec ich doświadczeń związanych z zakończeniem edukacji. Lęk rodziców o przyszłość dziecka, strach przed nieznanym czy pójściem do pracy - wszystko to stanowiło dla badanych pewną ramę dla ich osobistego zmagania się z przejściem ze szkoły (a więc środowiska "oswojonego" i bezpiecznego, w którym spędzili kilkanaście lat) do nowego środowiska. W moim odczuciu badani dobrze poradzili sobie z tym ciężarem rodzicielskich obaw, choć dobrze pamiętają, że dla rodziców nie było to łatwe doświadczenie. 
Oczywiście doświadczenia edukacyjne badanych obejmują też doświadczenia, którym sami nadają negatywne znaczenia. W kontekście teraźniejszych doświadczeń związanych ze wsparciem badane przeze mnie osoby same wybierały podczas wywiadów te wydarzenia edukacyjne, które były odczuwane przez nich jako trudne.

Sytuacja wywiadu grupowego ośmielała ich niewątpliwie do tego:

"Ja: Jak Ty wspominasz Maja szkotę?

M: Nie lubiłam w szkole tego, że jak wychodzitam na przerwy, to byłam bita przez kolegów. Bytam. Tego nie lubiłam.

Ja: A nie miataś tam koleżanek i kolegów?

M: Miałam przyjaciót. I nauczycieli lubitam też niektórych. Nie lubitam jak było dużo hałasu i dzieci krzyczaty. I panie krzyczaly na nas czasami.

K: Chodziłem na przerwę, jadtem śniadanie o 9. Później miatem wf z niesympatycznym panem Tomkiem. A potem zmienitem pana Tomka na... pana Piotra. On dał mi same szóstki. Dlatego byt sympatyczny bardzo. Pan Tomek krzyczał mocno na nas. I biegaliśmy tak... nie lubitem biegać. On krzyczat, że mogę biegać, bo na wózku nie jeżdżę ani tej... kuli nie mam... tego co się z tym chodzi. A ja nie mogtem już.

Ja: A mieliście w szkole kolegów czy koleżanki?

K: Piotrka miałam i Anię. I jeszcze Sylwia tam chodziła... i z nia się kolegowałem. Do szkoły nie lubitem jechać... no autobusem szkolnym. Musiatem na przystanku być i tam mnie autobus zabierał. Mama się bała jak jechatem tym autobusem.

M: Na przystanek mama mnie odprowadzała codziennie. A później mama napisała pisemko, że chce sama wracać z autobusu. I prosto do domu sztam później.

Ja: Lubiliście szkotę?

Ł: Lubię Warsztat. W szkole to mi nie szto... to czytanie... i te cyferki pisać nie lubitem. W domu mama data mi pisanie, a ja płakałem. Nie lubię tego pisania. Kuchnię lubię. I sprzatanie.

E: Jak nie chcę to nie piszę. Tam musiałem.

Istotną kwestią dotyczącą przejścia ze szkoły do WTZ, wspólną dla wszystkich badanych, stało się "osadzenie" w doświadczaniu bycia dorosłym. Edukacja jest dla moich rozmówców doświadczeniem „zamkniętym”. Dorosłość jest tu jednak ich specyficzną dorosłością, którą każdy z nich definiuje nieco inaczej, choć występuje wyraźny wspólny element. Tym elementem są ich prawa i przywileje, które mogą realizować w warsztacie. Choć badani nie używają słowa "prawa", to jednak z kontekstu ich wypowiedzi wynika, iż chodzi tu o korzystanie z życia na innych zasadach niż dotychczas.

Oto fragmenty narracji pochodzące z wywiadów indywidualnych, w których badani odnosili się do własnej dorosłości w kontekście korzystania ze wsparcia w warsztacie. 
Ł: Już dzieckiem nie jestem przecież. Tu dużo robię. Cały czas pracuję (...) i nie podoba mi się, że w tej kuchni się pokłóca... to jak się kłócą to wychodzę (...) Mogę nie przyjść i zwolnienie przyniosę, i zadzwonię do kierownika, to mu powiem, że nie przyjdę... bez zwolnienia. Mama nie musi dzwonić. Ja sam.

A: Ja tu pracuję. Sprzątam i na kuchni jestem. Koloruję potem dużo. I te teczki mam (...) A jak nagrodę dostałam za ten konkurs, to farby kupiłam i łańcuszek też (...) Normalnie jak człowiek tu mam (...) Dali mi nagrodę też.... różne takie rzeczy... i kubek. W szkole nie miałam nagród. Tylko mówili: rób to i to. Tu nie muszę robić jak nie chce.

K: Dorosty jestem przecież. Mama mówi, że ja już chłop... pracuję tu. W szkole jeździłem, a tu bliżej mam. I chodzę tu. A czasami mama przychodzi po mnie, bo zakupy robi (...), ale ja potrafię przyjść sam. I szatnia jest to tu... wszystko zostawiam jak ćwiczyć idę. Pan Kierownik też ćwiczy. Normalnie. Ja też.

M: Lubię przychodzić... bo gdzie w domu mam być? Siedzieć tak (...) Pić kawę i z psem wyjść mogé, ale idę tu. Mama też idzie do pracy. I ja też tu. Sprzątać nie lubię. Ciężko jest. W kuchni coś robię i gotujemy. W domu też robię teraz. Kiedyś nie. Tu już robiłam zupy i kanapki te... (...) i mama w domu pozwala... bo w Warsztacie robię.

W powyższych fragmentach uwidacznia się osobiste uwikłanie moich rozmówców, choć każdy z nich (nie pytany o to ani nie skłaniany do takiej interpretacji) przyjmuje jakąś wizję siebie w tej placówce w kontekście nie bycia już dzieckiem, a byciem dorosłym. W warsztacie, jako nowym dla siebie środowisku, każde z nich musiało się jakoś odnaleźć.

\section{Miejsce spotkań}

Warsztat dla badanych przeze mnie osób jest również miejscem nawiązywania i podtrzymywania relacji. Ten watek pojawiał się bardzo często w wypowiedziach moich rozmówców. Badani wyraźnie zaznaczali, iż istotny dla nich jest fakt, że w warsztacie mają wpływ na to, w jakiej grupie (czyli z kim) będą mieli zajęcia. W WTZ, z którego wsparcia korzystają badani, jest stałe przypisanie do danej pracowni, ale jest też dość bogata oferta zajęć, które odbywają się poza pracowniami. Zajęcia te nie są przymusowe. Uczestnicy mogą wybierać dowolne zajęcia lub też po czasie zamienić je na takie, które podobają im się bardziej.

Oto wybrane fragmenty indywidualnych narracji, w których osoby badane poruszały ten wątek. Zwraca tu uwagę kontekst, który dotyczy nawiązywania czy też podtrzymywania relacji z innymi.

K: Na zajęciach to gadamy sobie o różnych takich (...) a jak byłem na zajęciach u pani Ewy... to te zajęcia nie podobają mi się. Gadaliśmy tam.. hm... no nie wiem. Nie chodzę już tam. Śpiewaćlubię i w przedstawieniu gram. Lubię. Chodzę na zajęcia do pani Doroty. 
Ł: W mojej grupie lubię sprzątanie (...) Kuchni nie lubię za bardzo. Czasami lubię i muszę w kuchni pracować i sprzatać. Na zajęcia na dole nie lubię chodzić. Siedzieć lubię i rysować... a oni ida na dót. Ja nie idę.

A: Jestem sama, bo tam u mnie same chłopaki i ja. I byłam u kierownika, i mówiłam wszystko. Zmienić chcę grupę. Same chtopaki są. Chciałabym mieć koleżankę jakaśs. Jak pan kierownik się zgodzi, to przyjdzie do mnie koleżanka. W grupie będzie.

M: Nie za bardzo zadowolona jestem. Nie nadażam za wszystkimi co robia. (...) Jestem zadowolona z zajęć na sali. Z ćwiczeń. Bardzo. Pomaga mi to. Lepszy humor mam. Będęchodzić tam. I fajnie sobie gadamy. I Pawet tam chodzi też.

Badani oczywiście bywają niezadowoleni ze swoich wyborów lub z tego, że muszą czekać na zgodę terapeuty lub kierownika na zmianę grupy czy też zajęć, na które wcześniej zadeklarowali, że będą chodzić. Charakterystyczne dla moich rozmówców jest używanie określeń: „mój” pan czy „moja” pani w odniesieniu do terapeutów. Badane przeze mnie osoby mają silne poczucie przynależności do swojej pracowni i używają określeń: „moja” czy też „mój” w odniesieniu tylko do tych terapeutów, którzy prowadzą pracownię, do której zostali przydzieleni.

Ich odczucia dotyczące własnej grupy w dużej mierze podyktowane są sympatiami i antypatiami w stosunku do kolegów czy koleżanek. W placówce zdarzają się kłótnie czy też wzajemne dowody sympatii podyktowane przyjaźnią. Badane przeze mnie osoby z niepełnosprawnością intelektualną najczęściej używały określeń: „kolega”, „koleżanka” czy tė̇ „kolegowanie się”.

W warsztacie zdarzają się też pary, choć w placówce, do której uczęszczają badani, w przypadku osób z niepełnosprawnością intelektualną to "bycie parą" ogranicza się tylko do „bycia parą” w placówce. Poza warsztatem kontakt takiej pary jest sporadyczny lub nie ma go wcale.

Wszyscy moi rozmówcy postrzegają jednak warsztat również jako potencjalne miejsce nawiązywania relacji damsko-męskich. Badani mają nadzieję na poznanie chłopaka czy dziewczyny.

Oto wybrany fragment wywiadu grupowego, który dobrze ilustruje te kwestię:

M: Ja mam chtopaka z kościoła, ale jak nie będę go mieć, to poznam tu kogoś sobie w Warsztacie.

Ł: Nie mam dziewczyny, ale fajne tu sa dziewczyny. Podoba mi się Martyna, ale ona ma Pawła.

M: Martyna kocha Pawła.

Ł: A Pawet pójdzie niedtugo do pracy i Martyna będzie... ptakać.

M: Nie będzie cię chciała.

Ł: A właśnie, że będzie!

K: A ja nie mam dziewczyny... Nie mogę... bo mi rentę zabiora.

Ja: Jak to... rentę zabiora? 


\section{A: Gtupoty gadasz!}

K: Nie gadam. A jak żenić się będę to do pracy pójdę... i rentę zabiorą.

A: Gtupoty!

K: A co tam z mamą będę mieszkać i z żoną.

Ł: Mieszkanie kupisz.

Ł: Za co?

M: Dostajesz kieszonkowe w Warsztacie.

A: Mało tu mamy pieniędzy.

Badani wyrażają pragnienie bycia z kimś czy też mają sami nadzieję na poznanie kogoś w warsztacie, z kim mogliby tworzyć związek. Uważam, iż wypowiedź Krzysztofa zawiera w sobie echa rozmów o warsztacie czy też swojej przyszłości jakie toczy ze swoją mamą. Wielokrotnie podczas rozmów ze mną badany przywoływał wypowiedzi mamy i odnosił je do sytuacji, których doświadczał i o których opowiadał. Również w tym kontekście wyrażał obawy o przyszłość. Stąd jego wypowiedź dotycząca zabrania renty powinna być odczytywana jako pewne echo rozmów z mamą. Zapewne mama Krzysztofa boi się, że syn mógłby usamodzielnić się czy też nawiązać bliższą relację z kobietą.

\section{Miejsce pracy}

Badane przeze mnie osoby w narracjach dość często poruszały temat pracy. Specyficzną kwestią było używanie przez nich takich określeń, jak: „praca” czy "pracować", w odniesieniu do aktywności, które są ich udziałem w placówce. Praca jest niewątpliwie dla moich rozmówców dowodem na realizowanie własnej dorosłości. Oczywiście zapytani o to czy chcieliby pracować poza warsztatem, nie reagowali entuzjastycznie na taki pomysł. Trudno też im było się jednoznacznie ustosunkować do takiej ewentualności.

Oto wybrany fragment wywiadu grupowego, podczas którego ta kwestia pojawiła się:

K: Do pracy nie idę... rentę zabiorą i co.

Ł: Na warsztaty będę chodzić. Tu pracuję i już.

A: Ja nie mogę do pracy iść, bo mam te papiery i legitymację taka. I pieniądze dostaję. I zakupy robię.

M: Do pracy? Mama nie zgodzi się. Pieniądze zabiora. Tam ciężko. Trzeba zamiatać i układać. Ja tu robię... sprzatam... Tu pracuję.

Wszystkie badane przeze mnie osoby odrzucały możliwość podjęcia pracy poza warsztatem, ale również wszystkie nadawały znaczenie pracy swojej aktyw- 
ności w miejscu wsparcia. Ich indywidualne koncepcje, co to znaczy „pracować” i na czym praca $\mathrm{w}$ warsztacie polega, różniły się od siebie, ale wszyscy nadawali znaczenie pracy podobnym aktywnościom.

Poniżej przytaczam fragment wywiadu grupowego, podczas którego pojawił się zainicjowany przez moje pytanie wątek dotyczący pracy:

Ja: A co to jest ten Warsztat? Co tu się dzieje?

K: Przygotowanie do zawodu tu jest.

M: I chodzimy na spacery... i kuchnię mamy... Myślę że Warsztat to jest, żeby się uczyć na przysztość... uczyć gotowania, chodzić na wf, ćwiczenia. Najbardziej na kregle lubię chodzić.

Ja: A czego nie lubisz?

M: Czego nie lubię? Kuchni nie lubię najbardziej.

K: Ja lubię tu przychodzić A chciałbym być najlepiej pomocnikiem kucharza. Lubię... obierać ziemniaki, warzywa, kanapki robić.

$\mathrm{J}$ : A co tu najczęściej w Warsztacie robicie?

K: Robimy tu pudetka i choinki takie. Ja w Warsztacie wszystko lubię robić. Nawet wf lubię. Wszystkich tu lubię. Ale Ania mnie nie lubi... bo powiedziała, że jestem taki... że ja... No, nie wiem jak to powiedzieć... No my sobie dokuczamy.

Ł: Pracuję tu. Sprzątam i ćwiczę.

A: I rysuję i maluję.

M: Rysowanie to nie praca.

K: To nie praca.

Ja: Dlaczego to nie praca?

M: Bo to w wolnym czasie się robi. Rysuję w domu. też rysuje w domu.

Ł: Rysowanie to nie praca.

Ja: A śpiewanie i zajęcia teatralne to praca?

M: To też nie praca.

Ł: Śpiewamy tylko i występy mamy.

A: To takie występy sa jak rodzice przyjda, na święta albo na sali śpiewamy. Sprzatamy i w kuchni robimy i to jest praca.

$\mathrm{W}$ powyższym fragmencie uwidacznia się pewien proces uzgadniania znaczeń przez badanych. Dylemat, jaki pojawił się podczas rozmowy badanych przeze mnie osób, dotyczył nadawania pewnym aktywnościom znaczenia pracy. Działania artystyczne nie są przez badanych jednoznacznie określane jako praca. Nawet jeśli Agnieszka wymieniła rysowanie jako pracę, to pod wpływem wypowiedzi innych osób szybko zmieniała zdanie i przyznała, iż rysowanie czy malowanie pracą nie jest. To samo dotyczy zajęć muzycznych czy teatralnych. Badani wspólnie uzgadniają, że są to zajęcia innego rodzaju. 
W indywidualnych narracjach badani również często wracali do tematu pracy oraz do rozstrzygnięcia, jakie aktywności są dla nich pracą a jakie nie. Uważam, że w przypadku badanych przeze mnie osób, to co nazywają „pracą” w warsztacie, jest dla nich źródłem satysfakcji i radości oraz daje im możliwość poczucia się kompetentnym i przydatnym. Badani nie zawsze doświadczają tego w domach rodzinnych.

O tym jak istotną kwestią dla moich rozmówców jest aktywność, której mogą doświadczać w warsztacie, świadczą między innymi poniższe wybrane fragmenty ich narracji indywidualnych:

K: Introligatorem bym chciał być, bo chciałem oprawiać książki. To trudne... aby obłożyć książki taka folia żeby się ni niszczyła... żeby brudnymi łapami nie dotykać. Trzeba mieć czyste ręce. Trzeba być w bibliotece cicho... bo trzeba tam czytać ksiażki. W Warsztacie obkładam ksiażki.

A: Tak mi się nie chce czasem pracować, ale trzeba. W domu odpocznę sobie i pogadam z mama i powiem co tam robiłam na warsztatach dziś... że układałam i zamiatałam. I podłogę myłam i stoty też. I potem tylko przy komputerze w domu coś tam... pogram... i zjem... i spać już idę.

Ł: No nie chce mi się coś czasami. Zmęczony jestem i mam spóźnienia, ale muszę zrobić tam coś, bo mam dyżur. I wtedy w kuchni układam i kroję. Kanapki albo satatkę robimy. I zupę. Dla wszystkich. I terapeutów też. I kierownik je z nami. A potem sprzątam i zamiatam.

M: I umiem już... dużo rzeczy robię. Sama. Tata nie wierzy, że robię w kuchni. I on śmiał się ze mnie. Mama nakrzyczała na niego, żeby się nie śmiał. Ja dużo robię na warsztatach. Dużo.

Każda z badanych przeze mnie osób preferuje jakieś konkretne aktywności w warsztacie. Są również takie, których zdecydowanie nie lubią. Czasami ma na to wpływ terapeuta, który prowadzi te zajęcia. Czasami zaś są to czynności, z którymi mają pewien problem lub praca wydaje im się nudna czy też ciężka. W powyższym fragmencie bardzo symptomatyczne jest to co powiedziała Monika. Badana często wracała do osoby swojego taty i do tego, że tata nie wierzy w nią. W jej przypadku aktywność podejmowana w warsztacie (w kontekście wypowiedzi ojca) jest dla niej samej dowodem własnej samodzielności i niezależności.

\section{Podsumowanie}

W zebranym materiale badawczym, w wyniku analizy zebranych danych jakościowych, wyłoniłam cztery główne kategorie, wokół których ogniskowały się znaczenia nadawane warsztatowi, do którego uczęszczali badani.

Dla wszystkich badanych przeze mnie osób warsztat jest elementem ich codziennego życia. Pozwala im na różnorodne codzienne doświadczenia. Życie badanych nie ogranicza się do funkcjonowania tylko w środowisku rodzinnym. Ta „warsztatowa” codzienność jest przez nich dobrze „oswojona”. Badani znają 
w warsztacie swój rozkład dnia i tygodnia. Wiedzą jakie zajęcia odbywają się $\mathrm{w}$ danym czasie i jak one przebiegają. Rutyna dnia codziennego jest dla nich czymś dobrym. Uważam, że czują się w tym środowisku bezpiecznie.

Dla badanych przeze mnie osób warsztat jest również miejscem innym niż szkoła. Badani wyraźnie postrzegają różnice pomiędzy szkołą a warsztatem. Mają różnorodne doświadczenia edukacyjne i stanowią one dla nich niewątpliwie ważny punkt odniesienia do ich obecnej codzienności. W tym kontekście jednym z istotnych znaczeń podzielanych przez wszystkich moich rozmówców jest to, że uczęszczanie do warsztatu jest dla nich samych pewnym świadectwem dorosłości. I choć ich indywidualne koncepcje dorosłości różnią się od siebie, to niewątpliwie każda z badanych przeze mnie osób czuje się dorosła, a warsztat jest według nich miejscem właśnie dla dorosłych osób.

Wszystkie badane przez mnie osób w swoich narracjach często przywoływały istotny dla siebie (w kontekście korzystania ze wsparcia w warsztacie) aspekt nawiązywania i podtrzymywania relacji. Dla badanych warsztat jawi się jako miejsce spotkań i różnych interakcji. Moi rozmówcy w warsztacie posiadają wśród innych uczestników grono osób, z którymi czują się dobrze. Czasami nie są zadowoleni z konkretnej relacji. Nie zawsze jest formalna możliwość, aby zapewnić każdemu z nich przebywanie tylko z osobami, które akceptują i lubią. Każdy $z$ nich ma inne cechy charakterologiczne i uważam, iż one w dużej mierze rzutują na jakość ich relacji w warsztacie.

Dla wszystkich badanych przeze mnie osób warsztat jest miejscem pracy. Oczywiście w przypadku każdej z badanych przeze mnie osób znaczenia nadawane pracy różnią się do siebie, bowiem są związane z indywidualnym kontekstem biograficznym. Praca w warsztacie jest przez badanych rozumiana jako pewne czynności podejmowane przez nich w placówce. Badani nie zawsze mają ochotę na wysiłek, ale każdy z nich zdaje sobie sprawę, że jest to pewien ich obowiązek. Możliwość bycia aktywnym w warsztacie jest dla nich niewątpliwie źródłem satysfakcji. Wszystkie badane osoby wartościowały jako pracę przede wszystkim takie aktywności, jak: sprzątanie, prace gospodarcze czy pracę w kuchni. Aktywności, które mogą podejmować podczas zajęć o charakterze artystycznym czy ruchowym, zostały przez nich potraktowane raczej $w$ kategoriach rekreacji i wypełniania wolnego czasu.

\section{Bibliografia}

Bugajska B., Timoszyk-Tomczak C. (2010), Przeszłość - teraźniejszość - przyszłość. Kształtowanie zrównoważonej pespektywy czasowej w starości [w:] Elan vital v priestore medzigeneračných vzt́ahoj, Zbornik príspevkov z konferencie s medzinárodnou účastou, Beáta Balogová (red.), Univerzity v Prešove. 
Chodkowska M. (2014), Metoda biograficzna wobec wyzwań pedagogiki specjalnej, „Przegląd Badań Edukacyjnych", nr 18.

Chorążuk J. (2008), Raport z badania warsztatów terapii zajęciowej (Analiza porównawcza badań zrealizowanych w latach 2003 i 2005), Warszawa.

Lalak D. (2014), Badania biograficzne - standardy wiarygodności oraz walory edukacyjno-rozwojowe [w:] Aktywna biografia w przestrzeni społecznej, Wydawnictwo „Eko-inicjatywa”.

Łukasik J.M. (2013), Doświadczanie życia codziennego. Narracje nauczycielek na przełomie życia, Oficyna Wydawnicza „Impuls”, Kraków.

Pryszmont-Ciesielska M. (2014), "Świat społeczny w kalejdoskopie”, czyli o usytuowaniu badacza w badaniach jakościowych, "Teraźniejszość - Człowiek - Edukacja”, nr 65.

Sikorski W. (2005), Warsztaty terapii zajęciowej [w:] Formy opieki, wychowania i wsparcia w zreformowanym systemie pomocy społecznej, J. Brągiel, S. Badora (red.), Uniwersytet Opolski, Opole

Wolska D. (2016), Poziom umiejętności życiowych osób z głębszq niepetnosprawnościq intelektualna - beneficjentów zatrudnienia wspomaganego, „Niepełnosprawność. Dyskursy Pedagogiki Specjalnej", nr 24 .

Zakrzewska-Manterys E. (2014), Badanie sytuacji Warsztatów Terapii zajęciowej. Raport końcowy $z$ badania, PFRON, 2014.

Badanie sytuacji Warsztatów Terapii zajęciowej. Raport końcowy z badania, PFRON, 2014.

Zakrzewska-Manterys E. (2010), Upośledzeni umysłowo. Poza granicami człowieczeństwa, WUW, Warszawa. 